\title{
Sensitivitas Antibakteria Dari Tanaman Caulerpa sp. Dan Enteromorpha sp. Terhadap Bakteri Vibrio alginolyticus
}

\author{
Antibacterial Sensitivity Of Caulerpa sp. And Enteromorpha sp. Plants Toward Vibrio \\ alginolyticus Bacteria
}

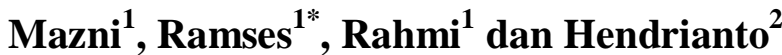 \\ ${ }^{1}$ Program Studi Pendidikan Biologi, FKIP, Universitas Riau Kepulauan, Batam \\ ${ }^{2}$ Balai Perikanan Budidaya Laut (BPBL) Setokok, Batam \\ Koresponden : ramses.firdaus@gmail.com
}

\begin{abstract}
Abstrak
Tanaman Caulerpa lentillifera, Caulerpa racemosa dan Enteromorpha compressa tergolong tanaman makroalga yang hidup di perairan laut dangkal dan banyak dijumpai di perairan Batam, Kepulauan Riau. Spesies makroalga berpotensi memiliki senyawa bioaktif sebagai antibakteri seperti spesies C.lentillifera, C.racemosa dan E.compressa. Tujuan penelitian ini untuk mengetahui adanya respon Sensitivitas Antibakteria dari Tanaman Caulerpa sp. dan Enteromorpha sp. Terhadap Bakteri Vibrio alginolyticus diaplikasikan dalam Pembuatan Media Pembelajaran Accordion Book Pada Materi Bioteknologi. Penelitian ini dilaksanakan pada bulan Februari-April 2018 di Laboratorium Penguji Kesehatan Ikan dan Lingkungan Balai Perikanan Budidaya Laut Batam (BPBL). Sampel makroalga diperoleh dari perairan Pulau Sarang, Kecamatan Belakang Padang, Kota Batam. Isolat murni bakteri berasal dari BPBL Batam. Metode yang digunakan dalam penelitian ini adalah eksperimental laboratoris. Uji sensitivitas terhadap bakteri $V$. alginolyticus dilakukan dengan metode difusi cakram Kirby-Bauer. Kertas cakram yang digunakan berukuran $5 \mathrm{~mm}$. Pengukuran diameter zona hambat dilakukan pada masa inkubasi 6,12,18,24 jam. Analisis data menggunakan teknik analisis deskriptif. Berdasarkan hasil penelitian bahwa adanya respon sensitivitas antibakteria dari tanaman C.lentillifera, C.racemosa dan E.compressa terhadap bakteri V.alginolyticus pada uji maserasi, tetapi tidak untuk uji langsung dan uji ekstrak basah. Pada metode maserasi zona hambat dari tanaman C.racemosa sebesar $7 \mathrm{~mm}$, C.lentillifera sebesar 6,6 mm, dan E.compressa sebesar 6,3 mm termasuk kategori "Sedang" yaitu 5-10 mm.
\end{abstract}

Kata Kunci: Antibakteri, Sensitivitas, Makroalga, Caulerpa, Enteromorpha, Kepulauan Riau.

\begin{abstract}
Caulerpa lentillifera, Caulerpa racemosa, and Enteromorpha compressa plants that live in shoaled sea waters and found in the huge amount at Batam coastal, Kepulauan Riau province. The aims of this study were to determine the response of Antibacterial Sensitivity of Caulerpa sp. and Enteromorpha sp. Plants Toward Vibrio alginolyticus Bacteria Applied on Accordion Book as Learning Material on Biotechnology Material. This research was conducted in February-April 2018 at Fish and Environment Test Laboratory of Marine Fish Aquaculture Institute of Batam (BPBL). The macroalgae samples were obtained from the waters of Sarang Island, Belakang Padang district, Batam City. Isolate pure bacteria derived from BPBL Batam. The method used was this study laboratory experimental. Sensitivity tests for V. alginolyticus bacteria were performed by KirbyBauer disc diffusion method. The disc paper used was five $\mathrm{mm}$ in size. Data analysis used descriptive analysis technique. Based on the results of the research, the antibacterial sensitivity response of C.lentillifera, C.racemosa, and E.compressa to V.alginolyticus bacteria in the maceration test, but not for direct test and wet extract test. In the maceration zone method of C.racemosa plant of $7 \mathrm{~mm}$, C.lentillifera of $6.6 \mathrm{~mm}$, and E.compressa of $6.3 \mathrm{~mm}$ including the "Medium" category is 5-10 $\mathrm{mm}$.
\end{abstract}

Keywords: Antibacteria, Sensitivity, Macroalgae, Caulerpa, Enteromorpha, Riau Kepulauan 


\section{PENDAHULUAN}

Makroalga merupakan salah satu flora perairan laut yang banyak di jumpai di perairan laut dangkal Kota Batam, dan diduga memiliki kandungan senyawa bioaktif sebagai antibiotik alami. Makroalga dapat menjadi sumber senyawa bioaktif karena mampu menghasilkan beragam metabolit sekunder yang ditandai oleh spektrum aktivitas biologis yang luas. Senyawa ini berperan sebagai antiviral, antihelmintik, antijamur dan antibakteri telah terdeteksi pada makroalga hijau, coklat dan merah (Thirunavukkarasu, et al., 2013; Kolanjinathan, et al., 2014; Zhao, Yang dan Liu, 2016). Sebagian besar makroalga memiliki ekonomis yang tinggi dapat digunakan sebagai makanan dan obat-obatan tradisional. Dalam pengobatan tradisional makroalga digunakan untuk menurunkan panas, gangguan perut, dan gangguan ginjal (Singkoh, 2011). Anggur laut (Caulerpa sp.) merupakan salah satu jenis rumput laut yang bernilai ekonomis tinggi yaitu dapat dimanfaatkan sebagai obat, bahan makanan, dan pangan fungsional (Anwar, Bubun dan Rosmawati, 2016).

Caulerpa sp. dan Enteromorpha sp. merupakan jenis makroalga hijau yang berpotensi memiliki senyawa bioaktif sebagai antijamur dan antibakteri. Caulerpa sp. adalah rumput laut yang mahal, bermanfaat sebagai bahan makanan manusia juga diberikan kepada ternak (Romimohtarto dan Juwana, 2009), memiliki kandungan gizi berupa karbohidrat, protein, vitamin dan mineral (Saptasari, 2010). Ekstrak rumput laut Sargassum polycistum dan Gelidium sp. paling aktif menghambat pertumbuhan bakteri dari spesies Vibrio, sedangkan yang paling aktif terhadap bakteri Pseudomonas adalah Padina dan Caulerpa sp. (Izzati, 2007). Ekstrak metanol makroalga Caulerpa racemosa memiliki bahan aktif yang efektif sebagai antibakteri terhadap bakteri patogen Vibrio harveyi (Ikbal, 2015). Collins (1978) dalam Saptasari (2010) menyatakan zat caulerpicin dan caulerpin dapat diisolasi dari Caulerpa racemosa, Caulerpa sertulariodes, dan Caulerpa lentillifera. Aktivitas antimikroba yang terkait dengan ekstrak dari daerah thallus yang berbeda (apikal, basal dan stolon) dari spesies Caulerpa sp. terpilih (Caulerpa ashmeadii, Caulerpa paspaloides dan Caulerpa prolifera) juga dievaluasi. Hasil umumnya menunjukkan bahwa stolon Caulerpa sp. memiliki aktivitas antibakteri tertinggi (Kolanjinathan, et al., 2014).

Banyak penelitian telah merekomendasikan bahwa Enteromorpha sp. terkenal sebagai makanan bergizi dan rendah kalori yang kaya akan asam amino esensial dari manusia, asam lemak, vitamin, serat protein yang dapat tahan melewat usus tanpa diserap dan dapat mempertahankan komponen mineral. Enteromorpha sp. juga mengandung klorofil b dan 
berbagai jenis mineral, seperti kalsium, magnesium dan besi. Analisis kimia menunjukkan bahwa Enteromorpha sp. memiliki 9-14\% protein, 2-3,6 \% ekstrak eter, 32-36\% abu dan n-3 dan n-6 asam lemak 10,4 dan 10,9 g/ $100 \mathrm{~g}$ total asam lemak masing-masing. Polisakarida adalah komponen utama dari Enteromorpha sp. penggunaan dari polimer karbohidrat dari industri makanan, kosmetik dan farmasi untuk mikrobiologi dan bioteknologi (Zhao, Yang dan Liu, 2016).

Makroalga yang dapat menghasilkan zat antibakteri dan tentunya bisa digunakan sebagai antibiotik alami seperti pada budidaya perikanan yang terserang penyakit Vibriosis. Penyakit Vibriosis ini disebabkan oleh bakteri Vibrio, salah satunya V. alginolyticus. V.alginolyticus adalah bakteri gram negatif memproduksi sejumlah toksin-toksin dan faktorfaktor virulensi ekstracelluler yang membuatnya menjadi sebuah patogen yang berat ketika sistem imun dirusak (Kaufman, et al., 2002 dalam Luturmas dan Pattinasarany, 2010).

Pengujian sensitivitas antibakteri dari ekstrak Caulerpa sp. dan Enteromorpha $s p$. terhadap bakteri V.alginolyticus hanya sebatas melihat zona hambat dan tidak sampai pada analisis senyawa yang terdapat pada makroalga Caulerpa sp. dan Enteromorpha sp.

\section{METODE PENELITIAN}

Penelitian ini dilaksanakan pada bulan Februari-April 2018. Pengambilan sampel makroalga Caulerpa sp. dan Enteromorpha sp. dilakukan di perairan Pulau Sarang, Kelurahan Sekanak Raya, Kecamatan Belakang Padang, Kota Batam. Pengujian sensitivitas bakteri $V$. alginolyticus dilakukan di Laboratorium Penguji Kesehatan Ikan dan Lingkungan, Balai Perikanan Budidaya Laut, Setokok, Batam. Dilakukan tiga kali ulangan untuk metode ekstrak basah, metode uji langsung dan metode maserasi. Sampel makroalga yang dibutuhkan sebanyak 200 gram setiap jenisnya. Analisis data antibakteria yang dihasilkan dari tanaman uji dilakukan dengan analisis deskriptif yang menggambarkan adanya zona hambat yang terbentuk pada media kultur bakteri uji yang telah didifusikan dengan tanaman Caulerpa sp. dan Enteromorpha sp. Adanya zona hambat ditandai dengan adanya zona bening disekeliling kertas cakram. Pengukuran zona hambat dihitung dari diameter zona bening yang terbentuk. Diameter zona hambat yang terbentuk diukur dari sisi kiri sampai sisi sebelah kanan dengan menggunakan penggaris (Melki, Ayu dan Kurniati, 2011). 


\section{a. Isolasi dan Identifikasi}

Isolasi primer dan kultur bakteri V.alginolitycus dilakukan pada media TSA (Trypticase Soya Agar). Diinkubasi pada suhu $28-30^{\circ} \mathrm{C}$ selama 24 jam dan diidentifikasi. Identifikasi sifat biokimia $V$. alginolyticus berdasarkan buku Identifikasi Bakteri Patogen pada Ikan (Suherman, et. al., 2016). Identifikasi ini terdiri dari, bentuk koloni pada media agar TSA, uji $\mathrm{KOH}$ untuk uji Gram, uji oksidase, uji katalase, uji O/F (Oksidatif/Fermentatif), warna koloni pada media agar TCBS, uji indol, dan uji motilitas.

\section{b. Pembuatan Ekstrak Makroalga}

Pada metode ekstrak basah pelarut yang digunakan adalah akuades. Konsentrasi digunakan yaitu $100 \%$ dengan perbandingan (1:1 w/v). Sampel Caulerpa sp. dan Enteromorpha sp. ditimbang sebanyak 50 gram, dimasukkan kedalam cawan porselen dan digerus. Kemudian dimasukkan ke dalam $50 \mathrm{ml}$ akuades steril untuk pembentukan ekstrak. Direndam kertas cakram dalam larutan sampel selama 5 menit (Tari, 1999).

Pada metode uji langsung sampel Caulerpa sp. dan Enteromorpha sp. yang masih segar diperas langsung diatas paper disc tanpa bantuan pelarut untuk pembentukan ekstrak. Direndam kertas cakram dalam larutan sampel selama 5 menit. Pada metode maserasi sampel Caulerpa sp. dan Enteromorpha sp. yang diperoleh di lapangan terlebih dahulu dicuci bersih. Dijemur dibawah sinar matahari hingga kering. Sampel ditimbang sebanyak 5 gram kemudian dipotong halus-halus. Dimasukkan kedalam botol sampel dan dimasukkan etanol sebanyak $25 \mathrm{ml}$ kedalam botol sampel (1:5 w/v). Maserasi dilakukan selama 2 x 24 jam dengan pengadukan menggunakan inkubator shaker pada kecepatan $120 \mathrm{rpm}$ pada suhu $30^{\circ} \mathrm{C}$. Pengadukan bertujuan untuk mempercepat kontak antar sampel makroalga dan pelarut etanol yang digunakan. Setelah itu diuapkan diruangan terbuka selama 30 jam, proses penguapan ini bertujuan untuk menghilangkan pelarutnya yaitu etanol (Oktavianus, 2013; Natrah, et al., 2015).

\section{c. Pembuatan Medium MHA (Mueller Hinton Agar)}

Ditimbang MHA sebanyak 20,4 gram, dimasukkan kedalam labu erlenmeyer. Ditambahkan $\mathrm{NaCl}$ 2,5 \% sebanyak $600 \mathrm{ml}$, dimasukkan ke microwave sampai homogen. Setelah itu medium disterilisasi menggunakan autoclave pada suhu $121^{\circ} \mathrm{C}$ dengan tekanan 15 lbs selama 15 menit. Media didinginkan hingga suhu hangat pada waterbath $\left( \pm 50^{\circ} \mathrm{C}\right)$, tuang ke dalam cawan petri steril dilakukan dalam laminary air flow dan siap untuk digunakan (Shanmugam, Kathiresan dan Nayak, 2016). 


\section{d. Peremajaan Bakteri dan Pembuatan Suspensi Bakteri Uji}

Bakteri V. alginolyticus diambil sebanyak 1 ose dari stok bakteri, diinokulasi pada medium TSA, dan diinkubasikan secara terbalik pada suhu $30^{\circ} \mathrm{C}$ selama 24 jam. Setelah koloni bakteri tumbuh sempurna maka bakteri siap untuk di uji sensitivitasnya terhadap makroalga Caulerpa sp. dan Enteromorpha sp. (Purnama, Melki dan Rozirwan, 2011). Sebanyak 2 ose bakteri yang sudah diremajakan diambil dari media agar pada cawan petri. Dimasukkan ke dalam tabung reaksi yang berisi $\mathrm{NaCl}$ 0,9\% sebanyak $10 \mathrm{ml}$, kemudian divortex sehingga homogen. Disetarakan kekeruhannya dengan larutan standar McFarland $\left(1,5 \times 10^{8} \mathrm{cfu} / \mathrm{ml}\right)$.

e. Pelaksanaan Uji Sensitivitas Bakteri V. alginolyticus

Uji sensitivitas bakteri dilakukan terhadap satu jenis bakteri yaitu bakteri V.alginolyticus. Pengujian antibakteri dilakukan dengan metode difusi cakram. Sampel yang digunakan berasal dari tiga jenis makroalga yaitu C.lentillifera, Cracemosa, dan E.compressa. Pengujian dilakukan dalam tiga bentuk teknik yaitu metode ekstrak basah, uji langsung dan metode maserasi. Pada media MHA ditanam bakteri yang berasal dari suspensi bakteri uji dengan menggunakan swab cotton steril. Swab steril dicelupkan kedalam suspensi yang terdapat dalam tabung reaksi. Dengan gerakan menekan dan memutar lidi kapas tersebut pada dinding tabung bagian dalam. Kemudian lidi kapas tersebut diusapkan pada permukaan lempeng agar Mueller Hinton dan sebarkan secara merata pada permukaan agar tersebut. Diamkan selama 3-5 menit sampai mengering. Diletakkan kertas cakram yang berisi ekstrak pada permukaan agar dengan pinset. Biarkan selama 30 menit. Diinkubasi pada suhu $30^{\circ} \mathrm{C}$ selama 24 jam.

\section{f. Pengamatan dan Pengukuran Diameter Zona Hambat}

Penentuan zona hambat ditandai dengan adanya zona bening yang terbentuk disekeliling kertas cakram yang telah diinokulasi bakteri $V$. alginolyticus dilakukan dengan cara mengamati zona bening yang berada di zona terluar kertas yang mengandung ekstrak Caulerpa lentillifera, Caulerpa racemosa dan Enteromorpha compressa pada media agar yang telah diinokulasi bakteri $V$. alginolyticus. Hasilnya positif jika terbentuk zona hambatan di sekitar paper disk, dan hasil yang didapat akan negatif jika tidak terbentuk zona hambatan disekitar paper disk (Trianto, et al., 2004) 


\section{HASIL DAN PEMBAHASAN}

\section{a. Isolasi dan Identifikasi Bakteri Vibrio alginolyticus}

Karakteristik isolat murni bakteri V.alginolyticus diidentifikasi dengan berpedoman pada buku Identifikasi Bakteri Patogen pada Ikan (Suherman, et al., 2016). Hasil uji menunjukan bahwa bakteri $V$. alginolyticus ini memiliki morfologi bentuk koloni pada media TSA yang bersifat swarm (menyebar), bersifat Gram negatif (-) setelah diujikan menggunakan KOK 3\%, menghasilkan enzim katalase (+) dan oksidase (+), bersifat fermentatif (F), warna koloni pada media TCBS berwarna kuning (Y), indol terdapat cincin merah bersifat positif (+), dan bakteri ini bersifat motil (+). Hasil identifikasi bakteri V.alginolyticus dapat dilihat pada Tabel 1.

Tabel 1. Hasil Identifikasi Bakteri V.alginolyticus

\begin{tabular}{lc}
\hline \multicolumn{1}{c}{ UJI } & HASIL \\
\hline Bentuk Koloni pada TSA & Swarm \\
KOH 3\% & - \\
Oksidase & + \\
Katalase & + \\
O/F & $\mathrm{F}$ \\
Warna Koloni pada TCBS & $\mathrm{Y}$ \\
Indol & + \\
Motilitas & + \\
\hline
\end{tabular}

Keterangan: Swarm (menyebar); - (negatif); + (positif); F (fermentatif); Y (yellow)

Hasil penelitian ini serupa dengan hasil penelitian sebelumnya yaitu bakteri V.alginolyticus termasuk bakteri Gram negatif, bentuk koloni menyebar, oksidase dan katalase positif, bersifat fermentatif, motil dan indol positif (Nitimulyo, et. al., 2005; Luturmas \& Pattinasarany, 2010; Johnny \& Roza, 2014; Dahlia, et. al., 2017). Namun demikian dimungkinkan adanya perbedaan hasil uji karena perbedaan zat kimia yang digunakan dan tidak tertutup kemungkinan disebabkan oleh perbedaan asal isolate (Ramses, 2013).

b. Uji Sensitivitas Bakteri V. alginolyticus Terhadap Ekstrak Makroalga (Metode Ekstrak Basah)

Pada metode ekstrak basah konsentrasi yang digunakan yaitu 100\%. Pelarut yang digunakan adalah akuades. Berdasarkan hasil uji sensitivitas bakteri V.alginolyticus terhadap ekstrak makroalga C.lentillifera, C.racemosa dan E.compressa dengan metode difusi cakram Kirby-Bauer, tidak menunjukkan adanya zona hambat pada media MHA yang sudah ditanam bakteri V.alginolyticus. Untuk lebih jelasnya pengukuran diameter zona hambat yang 
dihasilkan oleh makroalga terhadap bakteri V.alginolyticus per waktu ( 0 jam dan 24 jam) dapat dilihat pada Gambar 1 .

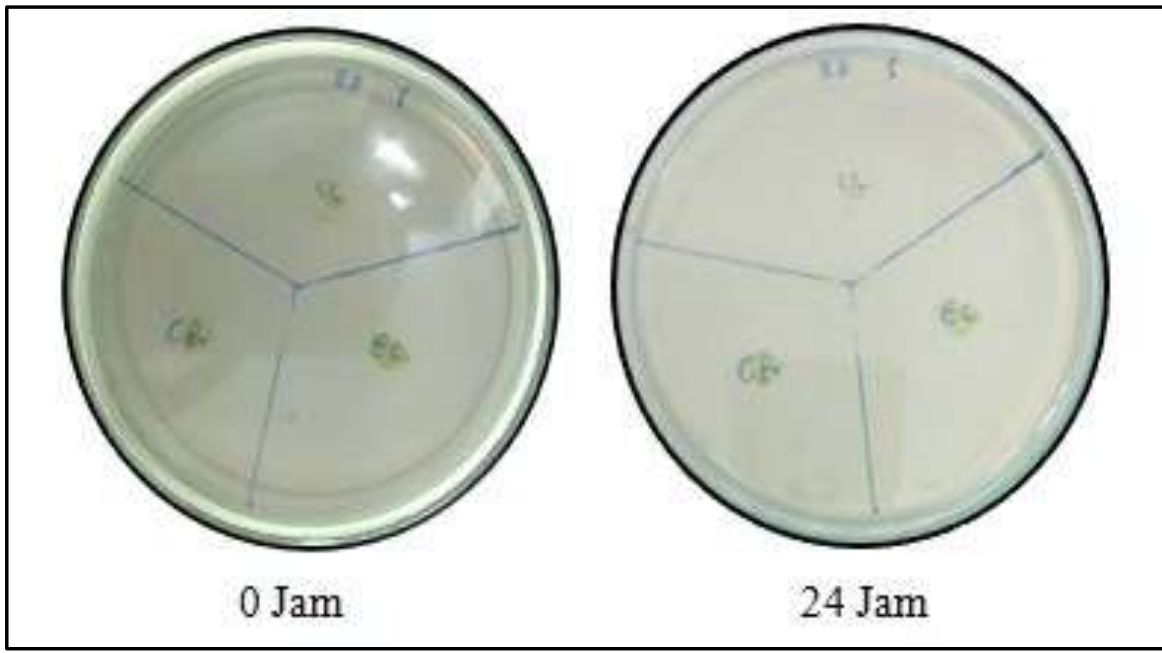

Gambar 1. Zona Hambatan pada Metode Ekstrak Basah. CL : C.lentillifera; CR : C.racemosa; EC : E.compressa

Pada masa inkubasi 24 jam tidak terbentuk zona hambat pada media MHA yang sudah ditanam bakteri V.alginolyticus. Hal ini disebabkan beberapa faktor yaitu jenis pelarut dan sifat pelarut yang digunakan. Pada ekstrak basah ini pelarut yang digunakan adalah akuades. Aquades merupakan pelarut yang sangat polar sehingga tidak dapat melarutkan senyawasenyawa organik atau senyawa non polar (Pavia, et. al., 1985 dalam Trianto, et. al., 2004), memiliki titik didih yang tinggi yaitu $100^{\circ} \mathrm{C}$ sehingga sulit untuk diuapkan (Susana, 2003). Pada akuades sulit diuapkan sehingga makroalga yang telah direndam menimbulkan pembusukan yang menyebabkan kerusakan pada senyawa yang terdapat dalam makroalga.

Selain itu diduga tidak terbentuknya zona hambat dikarenakan ekstraksi menggunakan pelarut akuades tidak mengeluarkan bahan bioaktif yang terdapat pada masing-masing makroalga. Pelarut memiliki efisiensi dan selektivitas yang berbeda untuk melarutkan komponen bioaktif serta untuk memisahkan zat yang diinginkan dari campurannya. Sifat polaritas bahan harus sama dengan polaritas pelarut agar bahan dapat larut. Faktor tersebutlah yang diduga mempengaruhi tidak terbentuknya zona hambat pada media MHA yang sudah ditanam bakteri V. alginolyticus (Sartika, Melki dan Purwiyanto, 2013).

c. Uji Sensitivitas Bakteri V. alginolyticus Terhadap Ekstrak Makroalga (Metode Uji Langsung)

Pada metode uji langsung ini tidak menggunakan bantuan pelarut. Berdasarkan hasil uji sensitivitas bakteri V.alginolyticus terhadap ekstrak makroalga C.lentillifera, C.racemosa dan 
E.compressa dengan metode difusi cakram Kirby-Bauer, tidak menunjukkan adanya zona hambat pada media MHA yang sudah ditanam bakteri V.alginolyticus. Sampel makroalga C.lentillifera, C.racemosa dan E.compressa yang masih segar masing-masing diperas langsung diatas paper disk. Untuk lebih jelasnya pengukuran diameter zona hambat yang dihasilkan oleh makroalga terhadap bakteri V.alginolyticus per waktu ( 0 jam dan 24 jam) dapat dilihat pada Gambar 2.

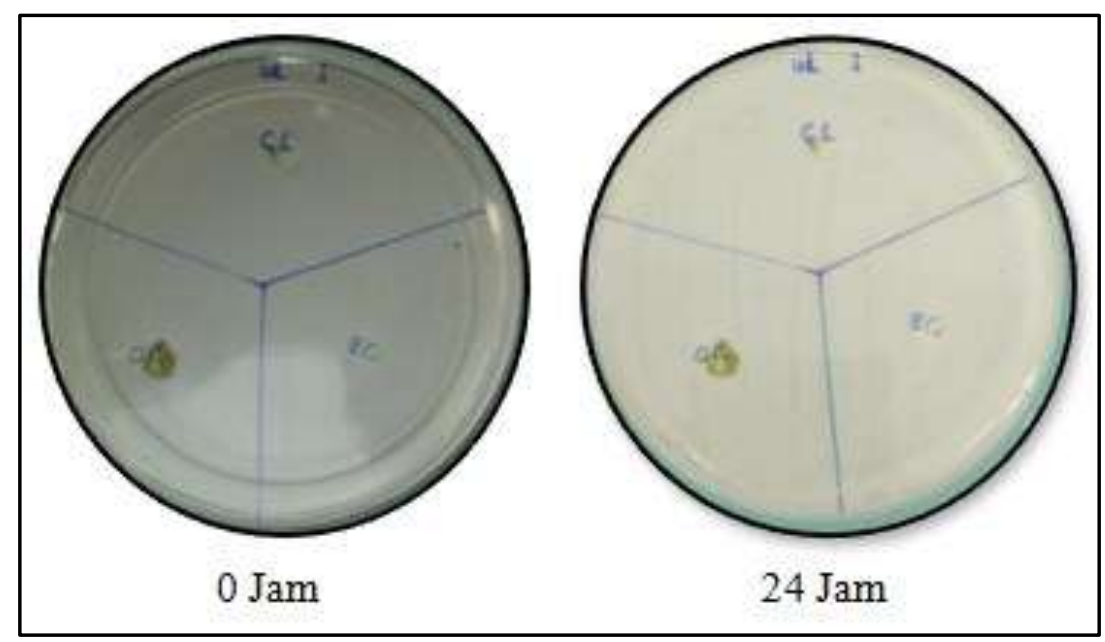

Gambar 2. Zona Hambatan pada Metode Uji Langsung. CL : C.lentillifera; $\mathrm{CR}:$ C.racemosa $; \mathrm{EC}:$ E.compressa.

Pada masa inkubasi 24 jam tidak terbentuk zona hambat pada media MHA yang sudah di tanam bakteri $V$. alginolyticus. Hal ini disebabkan karena pada metode uji langsung ini tidak adanya bantuan pelarut yang digunakan untuk mengeluarkan kandungan senyawa pada tanaman C.lentillifera, C.racemosa dan E.compressa. Pelarut merupakan salah satu faktor penting untuk memisahkan beberapa zat yang diinginkan dari campurannya (Sartika, Melki dan Purwiyanto, 2013).

\section{d. Uji Sensitivitas Bakteri V.alginolyticus Terhadap Ekstrak Makroalga (Metode Maserasi)}

Pada metode maserasi ini pelarut yang digunakan adalah etanol. Berdasarkan hasil uji sensitivitas bakteri V.alginolyticus terhadap ekstrak makroalga C.lentillifera, C.racemosa dan E.compressa dengan metode difusi cakram Kirby-Bauer, menunjukkan adanya zona hambat pada media MHA yang sudah di tanam bakteri V.alginolyticus. Hal ini ditandai dengan adanya zona bening yang terbentuk disekeliling kertas cakram. Untuk lebih jelasnya pengukuran diameter zona hambat yang dihasilkan oleh makroalga terhadap bakteri V.alginolyticus per waktu (0,6,12,18 dan 24 jam) dapat dilihat pada Gambar 3. 


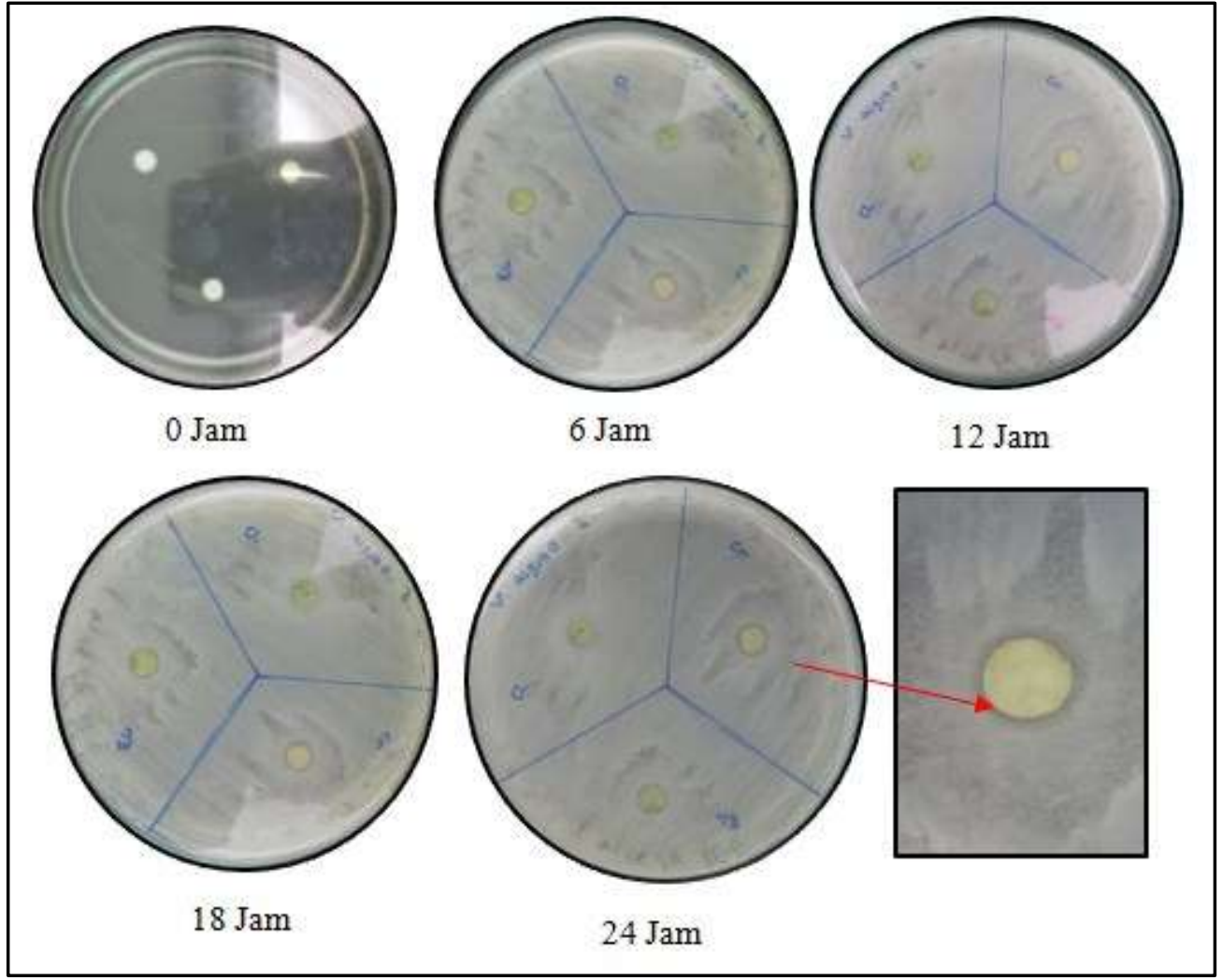

Gambar 3. Zona Hambatan pada Metode Maserasi. CL : Caulerpa lentillifera; CR: Caulerpa racemosa ; EC : Enteromorpha compressa

Besarnya rata rata diameter zona hambat dari ekstrak C.lentillifera, C.racemosa dan E.compressa terhadap bakteri V.alginolyticus per waktu (6 jam, 12 jam, 18 jam, dan 24 jam) dapat dilihat pada Tabel 2. Terdapat perbedaan besarnya zona hambat berdasarkan lama waktu inkubasi. Semakin bertambahnya waktu inkubasi zona hambat yang dihasilkan semakin kecil. Hal ini ditandai dengan terjadinya penurunan zona hambat setiap pengukuran 6 jam sekali hingga masa inkubasi 24 jam. Pada ekstrak C.lentillifera masa inkubasi zona hambat sebesar $6,6 \mathrm{~mm}$ turun menjadi $6 \mathrm{~mm}$ pada masa inkubasi 24 jam, pada ekstrak C.racemosa zona hambat sebesar $7 \mathrm{~mm}$ turun menjadi $6 \mathrm{~mm}$ pada masa inkubasi 24 jam dan ekstrak E.compressa zona hambat sebesar $6 \mathrm{~mm}$ kemudian pada masa inkubasi 12 jam terjadi kenaikan zona hambat sebesar $6,3 \mathrm{~mm}$, tetapi pada masa inkubasi 24 jam terjadi penurunan zona hambat menjadi $6 \mathrm{~mm}$. Perbedaan besarnya zona hambat berdasarkan lama waktu inkubasi disebabkan karena pertumbuhan bakteri cukup cepat pada masa inkubasi 6 jam hingga 24 jam. Sehingga ekstrak makroalga yang berfungsi sebagai antibakteria berperan hanya menghambat pertumbuhan bakteri $V$. alginolyticus tidak dapat mematikan bakteri. Proses ini di sebut bakteriostatik. 
Tabel 2. Diameter Zona Hambat dari Ekstrak C.lentillifera, C.racemosa, dan E.compressa terhadap Bakteri V.alginolitycus

\begin{tabular}{|c|c|c|c|c|c|}
\hline \multirow{2}{*}{ Sampel Makroalga } & \multirow{2}{*}{ Ulangan } & \multicolumn{4}{|c|}{ Rata-rata Zona Hambat (mm)/Jam } \\
\hline & & 6 & 12 & 18 & 24 \\
\hline \multirow{3}{*}{ Caulerpa lentillifera } & I & 6 & 6 & 6 & 6 \\
\hline & II & 7 & 6 & 6 & 6 \\
\hline & III & 7 & 6 & 6 & 6 \\
\hline \multicolumn{2}{|l|}{ Rata-rata } & 6,6 & 6 & 6 & 6 \\
\hline \multirow{3}{*}{ Caulerpa racemosa } & I & 7 & 7 & 7 & 6 \\
\hline & II & 8 & 6 & 6 & 6 \\
\hline & III & 6 & 6 & 6 & 6 \\
\hline \multicolumn{2}{|l|}{ Rata-rata } & 7 & 6,3 & 6,3 & 6 \\
\hline \multirow{3}{*}{ Enteromorpha compressa } & I & 5 & 6 & 6 & 6 \\
\hline & II & 7 & 7 & 7 & 6 \\
\hline & III & 6 & 6 & 7 & 6 \\
\hline Rata-rata & & 6 & 6,3 & 6,3 & 6 \\
\hline
\end{tabular}

Menurut Mycek (2001) dalam Putri (2016) bahwa suatu antimikroba bersifat bakteriostatik jika senyawa antimikroba tersebut hanya mampu menghambat pertumbuhan bakteri jika pemberian senyawa terus dilakukan dan jika dihentikan atau habis, maka pertumbuhan dan perbanyakan dari bakteri akan kembali meningkat yang ditandai dengan berkurangnya diameter zona hambatan. Sebaliknya bersifat bakteriosida jika diameter zona hambatan meningkat, hal ini disebabkan karena senyawa ini mampu membunuh dan menghentikan aktivitas fisiologis dari bakteri, meskipun pemberian senyawa tersebut dihentikan.

Hasil penelitian terdahulu menunjukkan adanya perbedaan terhadap diameter zona hambat disebabkan oleh beberapa faktor diantaranya kecepatan difusi, ukuran molekul dan stabilitas bahan antibakteri, sifat media yang digunakan, jumlah organisme yang diinokulasi, kecepatan tumbuh bakteri, konsentrasi bahan kimia serta kondisi pada saat inkubasi (Adriani, 2015). Hasil penelitian serupa adanya perbedaan terhadap diameter zona hambat disebabkan karena kemampuan setiap bakteri dalam melawan aktivitas antibakteri berbeda-beda tergantung pada ketebalan dan komposisi pembentuk dinding selnya (Melki, Ayu dan Kurniati, 2011); Sartika, Melki dan Purwiyanto, 2013). Selain itu perbedaan zona hambat disebabkan karena kandungan zat antibakteri yang terdapat pada ekstrak makroalga C.lentillifera, C.racemosa dan E.compressa berbeda-beda sehingga mampu menghambat pertumbuhan bakteri V.alginolyticus (Bachtiar, et al., 2012). 
Kemampuan setiap bakteri dalam melawan aktivitas antibakteri berbeda-beda bergantung ketebalan dan komposisi dinding selnya. Pada bakteri $V$. alginolyticus termasuk bakteri Gram negatif. Bakteri Gram negatif mengandung lipid, lemak atau substansi lemak dalam presentase lebih tinggi (11-22\%) dan dinding sel bakteri Gram negatif lebih tipis dan berlapis-lapis. Struktur bakteri Gram negatif memiliki membran lapisan luar yang menyelimuti lapisan tipis peptidoglikan, struktur luar peptidoglikan ini adalah lapisan ganda yang mengandung fosfolipid, protein dan lipopolisakarida. Mekanisme terjadinya penghambatan senyawa anibakteri makroalga terhadap pertumbuhan bakteri V.alginolyticus diduga karena terjadinya kerusakan komponen peptidoglikan pada sel bakteri, sehingga lapisan dinding sel tidak terbentuk secara utuh dan menyebabkan kematian sel tersebut (Pelczar \& Chan 2008).

Pada masa inkubasi 24 jam terbentuk zona hambat pada media MHA yang sudah di tanam bakteri V.alginolyticus. Hal ini disebabkan beberapa faktor yaitu senyawa bioaktif yang terdapat pada masing-masing makroalga berupa metabolit sekunder, jenis pelarut dan sifat pelarut yang digunakan. Pada metode maserasi ini pelarut yang digunakan adalah etanol, yang kemudian akan diserap oleh kertas cakram dan cepat menyebar pada media agar sehingga dapat menghambat pertumbuhan bakteri disekitarnya (Sartika, Melki dan Purwiyanto, 2013). Etanol disebut juga etil alkohol dengan titik didihnya $78,4^{\circ} \mathrm{C}$, memiliki titik didih yang cukup rendah membuat etanol mudah diuapkan. Etanol memiliki sifat tidak berwarna, volatil dan dapat bercampur dengan air (Kartika, et al., 1997 dalam Purba, 2009).

Penelitian serupa menurut Paul, et al (2007) mengidentifikasi senyawa aktif dari Caulerpa sp. dalam larutan metanol, berupa senyawa metabolit sekunder utama yaitu caulerpicin, caulerpenin dan caulerpin. Caulerpin adalah senyawa alkohol dengan rantai karbon alifatik panjang yang mempunyai gugus amina dan eter. Caulerpicin menimbulkan rasa pedas seperti lada. Caulerpenin adalah senyawa sesquiterpenoids yang mempunyai gugus aldehid. Senyawa ini bersifat toksik terhadap ikan-ikan herbivora dalam habitat terumbu karang. Senyawa lain yang merupakan senyawa aktif pada Caulerpa sp. adalah caulerpin. Senyawa ini berupa kristal prisma berwarna oranye kemerahan memiliki titik leleh $317^{\circ} \mathrm{C}$.

Sedangkan makroalga Enteromorpha sp. diduga mengandung senyawa bioaktif, berupa asam akrilat, benzaldehyde, asam butirat, senyawa terpenoid (1,8-cineol, d-limonene, geraniol, linalool), asam linoleat dan asam linolenat, methylamine, trimethylamine, isoamylamine, dan ethylamine untuk mengobati penyakit yang disebabkan oleh bakteri, virus, 
kanker, dan radang (Natalia, 2009). Untuk mengetahui perbandingan diameter daya hambat pada masing masing makroalga terhadap pertumbuhan bakteri V.alginolyticus pada metode maserasi dapat dilihat pada Gambar 4.

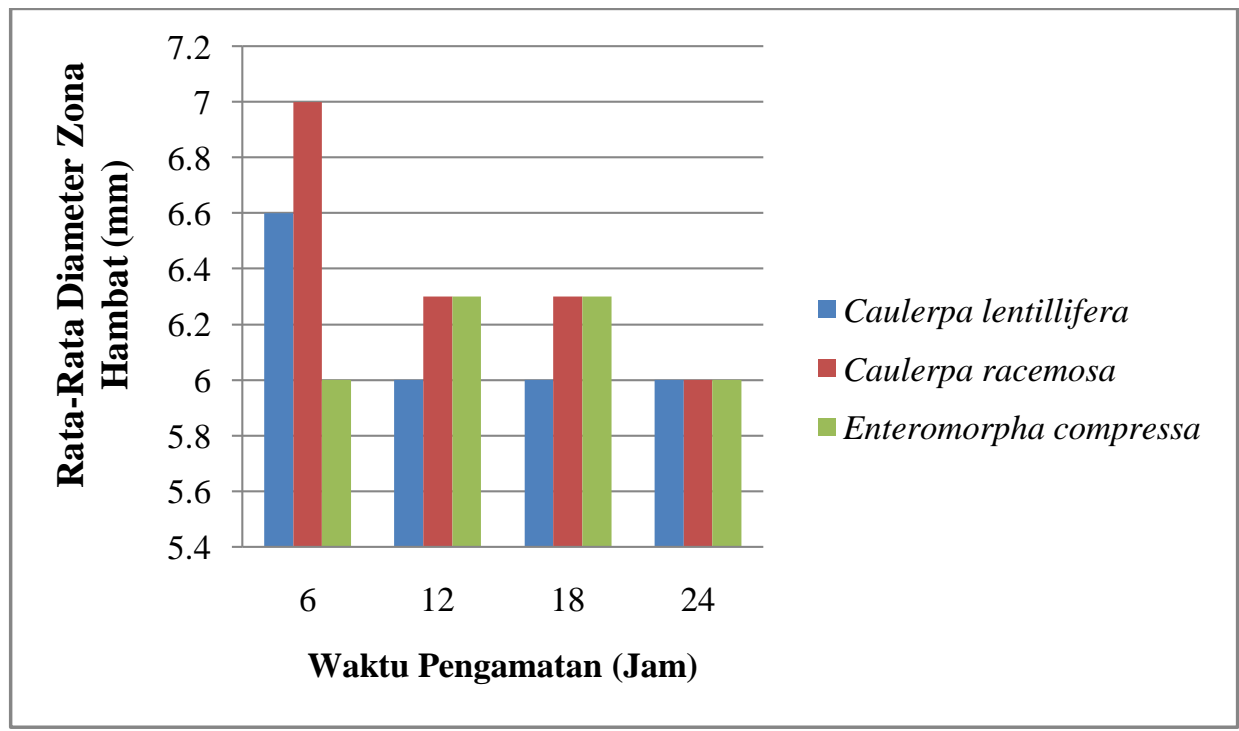

Gambar 4. Histogram Zona Hambat Bakteri V. alginolyticus Terhadap Makroalga Pada Metode Maserasi

Terjadi penurunan zona hambat dari semua ekstrak makroalga yaitu C.lentillifera, C.racemosa dan E.compressa jika dilihat dari rentang waktu masa inkubasi memiliki efek antibakteria terhadap pertumbuhan bakteri V.alginolyticus dengan kategori sedang pada pengamatan 6 jam sampai masa inkubasi 24 jam. Hal ini senada dengan pendapat Priyatmoko (2008) dalam Ikbal (2015) klasifikasi respon hambatan yang terbentuk pada uji difusi cakram terdiri atas empat kelompok yaitu respon lemah (diameter $\leq 5 \mathrm{~mm}$ ), sedang (diameter 5-10 $\mathrm{mm}$ ), kuat (diameter 10-20 mm), dan sangat kuat (diameter $\geq 20 \mathrm{~mm}$ ).

\section{KESIMPULAN}

Berdasarkan hasil penelitian bahwa adanya respon sensitivitas antibakteria dari tanaman C. lentillifera, C. racemosa dan E. compressa terhadap bakteri $V$. alginolyticus pada uji maserasi, tetapi tidak untuk uji langsung dan uji ekstrak basah. Pada metode maserasi zona hambat dari tanaman $C$. racemosa sebesar $7 \mathrm{~mm}, C$. lentiilifera sebesar $6,6 \mathrm{~mm}$, dan E.compressa sebesar 6,3 $\mathrm{mm}$ termasuk kekuatan hambat pada kategori sedang, dimana masih dalam kisaran 5-10 mm. 


\section{UCAPAN TERIMA KASIH}

Penelitian ini merupakan bagian dari penelitian dosen yang dibiayai oleh Universitas

Riau Kepulauan tahun anggaran 2017/2018 dengan nomor kontrak 03/KPPID/LPPM/II/2018.

\section{REFERENSI}

Adriani, 2015. Aktivitas Antibakterial Fungi Endofit Caulerpa racemosa Terhadap Bakteri Escherichia coli dan Staphylococcus aureus. Prosiding seminar Nasional Mikrobiologi Kesehatan dan Lingkungan. 11-15.

Anwar, L.O., Bubun, R.L. \& Rosmawati, 2016. Manfaat Anggur Laut (Caulerpa racemosa) dan Penanganannya dengan Melibatkan Masyarakat Pantai di Desa Rumba-Rumba. Seminar Nasional dan Gelar Produk, 17-18 Oktober.

Bachtiar, S.Y., Tjahjaningsih, W. \& Sianita, N., 2012. Pengaruh ekstrak alga coklat (Sargassum sp.) terhadap bakteri Eschericia coli. Journal Of Marine and Coastal Science, 1(1), 53-60.

Dahlia, Supprapto, H. \& Kusdarwati, R., 2017. Isolasi dan Identifikasi Bakteri Pada Benih Ikan Kerapu Cantang (Epinephelus sp.) dari Kolam Pendederan Balai Perikanan Budidaya Air Payau (BPBAP) Situbondo, Jawa Timur. Aquaculture and Fish Health, 6(2), 57-66.

Ikbal, M., 2015. Uji Toksisitas Ekstrak Metanol Rumput Laut Hijau (Caulerpa racemosa) pada Larva Udang Windu (Penaeus monodon). Octopus, 4(2), 417-42.

Izzati, M., 2007. Skreening Potensi Antibakteri pada Beberapa Spesies Rumput Laut terhadap Bakteri Patogen pada Udang Windu. Bioma, 9(2), 62.

Johnny, F. \& Roza, D., 2014. Infeksi Bakteri Vibrio alginolyticus Pada Lumba- Lumba Hidung Botol, Tursiops aduncus yang Dipelihara di Lovina, Singaraja, Bali [Infection of Bacterial Vibrio alginolyticus on Bottle Nose Dolphins, Tursiops aduncus Reared at Lovina, Singaraja, Bali]. Berita Biologi, 13(3), 295-300.

Kolanjinathan, K., Ganesh, P. \& Saranraj, P., 2014. Pharmacological Importance of Seaweeds: A Review. World Journal of Fish and Marine Sciences, 6(1), 1-15.

Luturmas, A. \& Pattinasarany, A.Y., 2010. Isolasi dan Karakterisasi Bakteri Vibrio alginolitycus pada Ikan Kerapu Tikus (Cromileptes altivelis) Sebagai Faktor Virulensi Bakteri Patogen. Seminar Nasional Basic Science II. 36-42. 
Melki, Ayu, W. EP, \& Kurniati, 2011. Uji Antibakteri Ekstrak Gracilaria sp (Rumput Laut) Terhadap Bakteri Escherichia coli dan Staphylococcus aureus. Program Studi Ilmu Kelautan FMIPA Universitas Sriwijaya, Palembang.

Natalia, W., 2009. Aktivitas Antibakteri Ekstrak Enteromorpha sp (Linn.) Terhadap Staphylococcus epidermidis (Winslow dan Winslow) dan Pseudomonas fluorescens (Migula) dengan Variasi Sifat Sampel dan Volume Metanol. (Skripsi). Universitas Atma Jaya, Yogyakarta.

Natrah, F. M. I., Harah, Z. M., Sidik, B. J., Izzatul, N. M. S., \& Syahidah, A., 2015. Antibacterial activities of selected seaweed and seagrass from port dickson coastal water against different aquaculture pathogens. Sains Malaysiana, 44(9), 1269-1273.

Nitimulyo, K. H., Isnansetyo, A., Triyanto, Istiqomah, I., \& Murdjani, M., 2005. Isolasi, Identifikasi dan Krakterisasi Vibrio sp. Patogen Penyebab Vibriosis pada Kerapu di Balai Budidaya Air Payau Situbondo. Jurnal Perikanan, VII(2), 80-94.

Oktavianus, S., 2013. Uji Daya Hambat Ekstrak Daun Mangrove Jenis Avicennia marina Terhadap Bakteri Vibrio parahaemolyticus. (Skripsi). Fakultas Ilmu Kelautan dan Perikanan Universitas Hasanuddin, Makassar.

Paul, V. j., Arthur, K. E., Ritson-Williams, R., \& Ross, C., 2007. Marine biological laboratory chemical defenses: from compounds to communities. Biol Bull, 213(December), 226251.

Pelczar, M.J. \& Chan, E.C.S., 2008. Dasar-Dasar Mikrobiologi. Penerjemah: Hadioetomo, R.S., Imas, T., Tjitrosomo, S.S. \& Angka, S.L., UI-Press, Jakarta, 443 hlm.

Purba, R.P., 2009. Produksi Etanol dengan Variasi Inokulum dan Kadar Pati Jagung Pada Kultur Sekali Unduh. (Skripsi). Fakultas Teknobiologi Universitas Atma Jaya, Yogyakarta.

Purnama, R., Melki, Ayu, W.EP, \& Rozirwan, 2011. Potensi Ekstrak Rumput Laut Halimeda renchii dan Euchema cottonii Sebagai Antibakteri Vibrio sp. Maspari Journal, Vo. 02, hal. 82-88.

Putri, S.U., 2016. Efek Ekstrak Makroalga Terhadap Bakteri Staphylococcus aureus dan Methicillin Resisten Staphylococcus aureus. (Skripsi). Fakultas Sains dan Teknologi Universitas Islam Negeri Alauddin, Makassar.

Ramses, 2013. Antagonisme Bakteri Bacillus sp dan Pseudomonas sp Terhadap Bakteri Vibrio parahaemolitycus Patogen Pada Udang Windu (Penaeus monodon fab). Dimensi, Vol. 2(2): 1-14

Romimohtarto, K. \& Juwana, S., 2009. Biologi Laut. Djambatan, Jakarta, 540 hlm.

Saptasari, M., 2010. Variasi ciri morfologi dan potensi makroalga jenis caulerpa di pantai kondang merak Kabupaten Malang. el-Hayah, 1(2), 19-22. 
Sartika, R., Melki \& Purwiyanto, A.I.S., 2013. Aktivitas antibakteri ekstrak rumput laut Eucheuma cottoni terhadap bakteri Escherichia coli, Staphylococcus aureus, Vibrio cholera dan Salmonella typhosa. Maspari Journal, 5(2), 98-103.

Shanmugam, A., Kathiresan, K. \& Nayak, L., 2016. Preparation, characterization and antibacterial activity of chitosan and phosphorylated chitosan from cuttlebone of Sepia kobiensis (Hoyle, 1885). Biotechnology Reports, 9(2016), 25-30.

Singkoh, M.F.O., 2011. Aktivitas Antibakteri Ekstrak Alga Laut Caulerpa racemosa dari Perairan Pulau Nain. Jurnal Perikanan dan Kelautan Tropis, VII(3), 123-127.

Suherman, Setya, S. D., Dinarti, Tusihadi, T., Evan, Y., \& Wibisana, R. I., 2016. Identifikasi Bakteri Patogen Pada Ikan. LP2IL Serang, Serang, 65 hlm.

Susana, T., 2003. Air Sebagai Sumber Kehidupan. Oseana, XXVIII(3), 17-25.

Tari, D.G.D., 1999. Sensitivitas Bakteri Aeromonas hydrophila Terhadap Tumbuhan Mangrove (Bruguiera gymnorrhiza, Rhizophora apiculata, Limnithzera littorea dan Tumbuhan Perdu). (Skripsi). Fakultas Perikanan dan Kelautan Universitas Riau, Pekanbaru.

Thirunavukkarasu, R., Pandiyan, P., Balaraman, D., Subaramaniyan, K., Edward, G., Jothi, G., ... Sadaiyappan, B., 2013. Isolation of bioactive compound from marine seaweeds against fish pathogenic bacteria Vibrio alginolyticus (VA09) and characterisation by FTIR. Journal of Coastal Life Medicine, 1(1), 26-33.

Trianto, A., Wibowo, E., Suryono, \& S, R. S., 2004. Ekstrak Daun Mangrove Aegiceras corniculatum Sebagai Antibakteri Vibrio harveyi dan Vibrio parahaemolyticus. Ilmu Kelautan, 9(4), 186-189.

Zhao, C., Yang, C. \& Liu, B., 2016. Biological Activities of Green Macroalgae Enteromorpha Prolifera for Potential Applications. Moj Food Processing \& Technology, 2(5), 1-4. 